\title{
Obstacles to the Promotion of Dialogue between Parents, Children and Health Professionals about Death and Dying in Pediatric Oncology
}

Messias Silvano da Silva Filho1, José Antonio de Lima Neto, Sonilde Saraiva Januário², Edglê Pedro de Sousa Filho², Uilna Natércia Soares Feitosa ${ }^{2}$,Emídio Antonio de Araújo Neto², Susanne dos Santos Rocha ${ }^{3}$, Modesto Leite Rolim Neto $^{1,2}$

\section{Abstract}

Despite advances in cancer treatments and improved prognosis, the number of deaths from the disease is high in the world. In Brazil, cancer is the second leading cause of death among children and adolescents, forcing family members, patients and professionals to deal with the issues of human finitude. The multidisciplinary team considers the discussions at the end of life as a difficult task to be performed on pediatric patients. The family is essential to overcome the communication barriers, acting as liaison between the multidisciplinary team and the patient. Children should be invited to participate in the decisionmaking process and their wishes should be honored at the end of life. Professionals should to be able to meet the physical, psychosocial, spiritual, social and cultural rights of patients and families. Discussions at the end of life with pediatric patients are key to promoting a "good death", however there are few studies that address this issue.
1 Faculty of Medicine, Estácio -FMJ, Juazeiro do Norte, Ceará, Brazil.

2 Postgraduate Program in Health Sciences, FMABC, Santo André, São Paulo, Brazil.

3 Medicine and Specialties Dr. Emídio, Cajazeiras, Paraíba, Brazil.

Contact information:

Modesto Leite Rolim Neto.

Đ modestorolim@yahoo.com.br

Keywords

End-of-life, Death, Pediatric Cancer, Palliative Care.
New cases of cancer are estimated 15,5 million in 2030 [1, 2, 3]. Although advances in cancer and supportive treatments have improved the prognosis and long-term survival rate of children with cancer, an estimated $25 \%$ of children will die of their disease $[4,5]$. In Brazil, in 2011, there were 2, 812 deaths due to cancer in children and adolescents (0-19 years). Neoplasms occupied the second position (7\%) of deaths of children and adolescents in 2011 [1, 6]. Therefore patients and their families are often forced to confront end-of-life (EOL) issues $[7,8,9]$ and although the specific impact of the loss of a child may 
differ for parents, a child's death is often considered the "ultimate loss" [10, 11].

End-of-life discussions (EOLd) with patients have been reported as one of the most difficult and stressful tasks for an oncologist [12, 13, 14]. However, few studies have dealt with EOLd in the pediatric setting $[12,15]$. Physicians have been trained to maintain health and fight illness, but they are generally provided little guidance regarding communication with dying patients and their families $[12,16]$. Pediatric oncologists reported "strong emotions" [17, 18]. These included sadness, crying, lack of sleep, feelings of exhaustion and being drained, feeling physically ill, and a sense of personal loss. The impact on oncologists included burnout, compartmentalization, emotional exhaustion, and difficulties inmaintaining emotional boundaries [17].

In that context, when a child is diagnosed with cancer, the entire family is diagnosed, therefore EOLd with pediatric patients will have some difference from that of adult patients [1, 19]. The most significant difference is that parents play an important role in the communication with the pediatric patient $[12,20,21]$. However, parents are usually, though not always, gatekeepers or conduits for communication between health professionals and the sick child [12, 22]. They decide what, when and how their child should be told about the illness [12, 23]. When an end-of-life decision has to be made for a child, most parents, independent of their country of origin, seem to prefer a shared approach by their physicians over a paternalistic approach or an informed approach $[24,25,26,27,28,29,30,31$, 32, 33].

Previous research suggests that open and honest communication among healthcare practitioners, parents and children about disease and prognosis is important for good medical care [34, 35, 36]. However, transitioning care from a primarily curative to palliative care focus is often challenging to negotiate [37]. Some barriers to adequate EOLd were identified in previous studies irrespective of patient age or disease. Among them, healthcare provider factors (the lack of experience, discomfort with death and dying [12, 38], lack of knowledge, uncertain prognosis [12, 39], uncertain right time to address the issue $[12,40]$ and reluctance to discussion $[12,41]$ and patient and parent factors (the inability of patients to comprehend, lack of readiness, unrealistic expectations [12, 40], family's opposition, [12, 38] lack of familial acknowledgement of terminal condition [12, 39], patient's willingness to protect other people and the inability to imagine a possible death $[12,41]$. So, Discussions of advance care planning frequently happen late in illness [37].

Parents of children with cancer and their clinicians prefer home as the location for EOL care and death [42]. But, Whenever possible, caregivers should make an effort to invite children to participate in medical decision making and honor their EOL care wishes [43]. The Institute of Medicine acknowledged that a critical component of the definition of a "good death" generally accords with the wishes of patients and families [42, 44]. Moreover, Regardless of the preferred location, when families are able to choose and plan the location of death, the dying process and bereavement experience both go more smoothly [7, 45].

What parents fear most is that their child will suffer in the process of dying [24]. It is recommended, in this sense, that the interdisciplinary team (IDT) identifies, communicates, and manages the signs and symptoms of patients at the EOL to meet the physical, psychosocial, spiritual, social, and culture needs of patients and families [46, 47]. Thus, the child's suffering from physical and psychological symptoms is reported as an important theme of pediatric palliative care, and illustrates the significance of adequate symptom management during the palliative phase $[10,48,49,50,51]$.

Children with cancer suffer proximal to death [52, $53,54]$ and but symptom control, despite efforts of health care professionals, is sometimes unsuccessful $[10,48,49,50,51]$. Therefore, understanding the 
degree of symptoms proximal to death and the predictors of those symptoms is an important step toward symptom management and optimization of quality of life in the end-of-life period [52].

Research should be conducted addressing EOLd with groups and children with similar age profiles, because the content of the barriers to these discussions can vary greatly from according to the age. Furthemore, it is necessary to identify the negative and positive point to EOLd in the pediatric setting and to calve what age children can be invited to participate in decision-making processes. Also, discussions at the end of life with pediatric patients should be performed whenever they are requested by patients and their parents. The family must to be part of the process, acting as a link between the child and the health professional. The multidisciplinary team should be prepared to meet the needs of the child-family binomial. This includes responding in a clear, precise and direct questions to the patients and their families about treatment, management of symptoms, prognosis, suspension of it and place of death therapy. It is essential that professionals follow the family before, during and after the death of children, minimizing the destructive effects of cancer diagnosis and mourning.

\section{References}

1. Freire, AM, Braga, HA, Braga, AA, Neto, MLR (2015). Hope And Pediatric Cancer. International archives of medicine. 8(61): 1-6.

2. World Health Organization (WHO) (2010). Cancer. Retrieved from http://www.who.int/mediacentre/factsheets/fs297/en/ index.html on 13 May 2010.

3. Kavradim ST, Ozer ZC, Bozcuk H. (2013). Hope in people with cancer: a multivariate analysis from Turkey. J Adv Nurs. 69(5): 1183-1196.

4. Verna L. Ferguson H, Akard T F, Madden J R, Herron A P, Levy R (2015). Contributions of Advanced Practice Nurses With a DNP Degree During Palliative and End-of-Life Care of Children With Cancer. Journal of Pediatric Oncology Nursing 32(1). 32-39.

5. Heron, M. (2011). Deaths: Leading causes for 2007. National Vital Statistics Reports, 59(8), 1-96.

6. (INCA) - Instituto Nacional de Câncer José Alencar Gomes da Silva. (2014). Coordenação de Prevenção e Vigilância Estimativa 2014: Incidência de Câncer no Brasil/Instituto Nacional de Câncer José Alencar Gomes da Silva, Coordenação de Prevenção e Vigilância. Rio de Janeiro: INCA.

7. Jacobs S, Perez J, Cheng YI, Sill A, Wang J, Lyon ME (2015). Adolescent End of Life Preferences and Congruence With Their Parents' Preferences: Results of a Survey of Adolescents With Cancer. Pediatr Blood Cancer. 62. 710-714.

8. Bleyer A. The adolescent and young adult gap in cancer care and outcome (2005). Curr Probl Pediatr Adolesc Health Care 35:182-217

9. Bleyer A. Adolescent and young adult (AYA) oncology: the firsta (2007). PediatrHematolOncol. 24:325-336.

10. Ivana, M.M. Geest, VG, Darlington ASE, Streng, IC, Michiels EMC, Pieters R, Heuvel-Eibrink, MMV (2014). Parents'Experiences of Pediatric PalliativeCare and the Impact on Long-Term Parental Grief. J Pain Symptom Manage. 47 (6). 1043-1053.

11. Wilson D (1999). The ultimate loss: the dying child. Loss Grief Care. 2. 125-130.

12. Yoshida S, Shimizu K, Kobayashi M, Inoguchi H, Oshima $Y$, Dotani C, Nakahara R, Takahashi T, Kato M (2014). Barriers of Healthcare Providers Against End-of-life Discussions with Pediatric Cancer Patients. Jpn J Clin Oncol. 44(8). 729-735.

13. Otani H, Morita T, Esaki T, et al (2011). Burden on oncologists when communicating the discontinuation of anticancer treatment. Jpn J Clin Oncol 2011; 41:999-1006.

14. Baile WF, Lenzi R, Parker PA, Buckman R, Cohen L. Oncologists' attitudes toward and practices in giving bad news: an exploratory study. J Clin Oncol 2002; 20:2189-96.

15. Durall A, Zurakowski D, Wolfe J (2012). Barriers to conducting advance care discussions for children with life-threatening conditions. Pediatrics. 129, 975-982. 
16. Mack JW, Wolfe J, Grier HE, Cleary PD, Weeks JC (2006). Communication about prognosis between parents and physicians of children with cancer: parent preferences and the impact of prognostic information. J Clin Oncol. 24, 5265-5270.

17. Granek L, Bartels U, Scheinemann K, Labrecque M, Barrera M (2015). Grief Reactions and Impact of Patient Death on Pediatric Oncologists. Pediatr Blood Cancer . 62:134-142.

18. Fanos JH. "Coming through the fog, coming over the moors.": The impact on pediatric oncologists of caring for seriously ill children. J Cancer Educ 2007; Summer; 22:119-123.

19. Jones BL. (2012). The challenge of quality care for family caregivers in pediatric cancer care. Semin Oncol Nurs. 28: $213-$ 220.

20. Quinn GP, Murphy D, Knapp C, et al (2011). Who decides? Decision making and fertility preservation in teens with cancer: a review of the literature. J Adolesc Health.49:337-46.

21. Clarke SA, Davies H, Jenney M, Glaser A, Eiser C (2005). Parental communication and children's behavior following diagnosis of childhood leukemia. Psychooncology. 14:274-81.

22. Scott JT, Harmsen M, Prictor MJ, Sowden AJ, Watt I (2003). Interventions for improving communication with children and adolescents about their cancer. Cochrane Database Syst Rev. 2003; 3:CD002969.

23. Young B, Dixon-Woods M, Windridge KC, Heney D (2003). Managing communication with young people who have a potentially life threatening chronic illness: qualitative study of patients and parents. BMJ. ; 326:305.

24. De vos MA, Bos AP, Plötz FB, Heerde MV, Graaff BM, Tates K, Truog RD, Willems DL (2015). Talking With Parents About End-of-Life Decisions for Their Children. PEDIATRICS. 135 (2): e465-e476.

25. Meert KL, Eggly S, Pollack M, et al (2008); National Institute of Child Health and Human Development Collaborative Pediatric Critical Care Research Network. Parents' perspectives on physician-parent communication near the time of a child's death in the pediatric intensive care unit. Pediatr Crit Care Med. 9(1):2-7

26. Meyer EC, Ritholz MD, Burns JP, Truog RD (2006). Improving the quality of end-of-life care in the pediatric intensive care unit: parents' priorities and recommendations. Pediatrics. 117(3):649657

27. Caeymaex L, Jousselme C, Vasilescu C, et al (2013). Perceived role in end-of-life decision making in the NICU affects longterm parental grief response. Arch Dis Child Fetal Neonatal Ed. 98(1): $\mathrm{f} 26-\mathrm{f3} 1$

28. Madrigal VN, Carroll KW, Hexem KR, Faerber JA, Morrison WE, Feudtner C (2012). Parental decision-making preferences in the pediatric intensive care unit. Crit Care Med. 40(10):2876-2882

29. Michelson KN, Koogler T, Sullivan C, Ortega MP, Hall E, Frader J (2009). Parental views on withdrawing life-sustaining therapies in critically ill children. Arch Pediatr Adolesc Med.163(11): 986992
30. Orfali K, Gordon EJ (2004). Autonomy gone awry: a crosscultural study of parents' experiences in neonatal intensive care units. Theor Med Bioeth. 25(4):329-365

31. Sullivan J, Monagle P, Gillam L (2014). What parents want from doctors in end-of-life decision-making for children. Arch Dis Child. 99(3):216-220

32. McHaffie HE, Lyon AJ, Hume R (2001). Deciding on treatment limitation for neonates: the parents' perspective. Eur J Pediatr. 160(6):339-344

33. Rapoport A, Shaheed J, Newman C, Rugg M, Steele R (2013). Parental perceptions of forgoing artificial nutrition and hydration during end-of-life care. Pediatrics. 131:861-869

34. Jalmsell L, Forslund3 M, Hansson MG, Henter JI, Kreicbergs $U$, Frost BM (2013). Transition to noncurative end-of-life care in paediatric oncology - a nationwide follow-up in Sweden. Acta Pædiatrica. 102: 744-748.

35. Beale EA, Baile WF, Aaron J (2005). Silence is not golden: communicating with children dying from cancer. J Clin Onc; 23: 3629-31.

36. Nitschke R, Meyer WH, Sexauer $C L$, Parkhurst JB, Foster $P$, Huszti $H$ (2000). Care of terminally ill children with cancer. Med Pediatr Oncol; 34: 268-70.

37. Polikoff LA, McCabe ME (2013). End-of-life care in the pediatric ICU. Emergency and critical care medicine. 25(3). 285-289.

38. Granek L, Krzyzanowska MK, Tozer R, Mazzotta P (2013). Oncologists' strategies and barriers to effective communication about the end of life. J Oncol Pract; 9:e129-135.

39. Davies B, Sehring SA, Partridge JC, et al (2008). Barriers to palliative care for children: perceptions of pediatric health care providers. Pediatrics; 121:282-8.

40. Durall A, Zurakowski D, Wolfe J (2012). Barriers to conducting advance care discussions for children with life-threatening conditions. Pediatrics; 129:e975-82.

41. Curtis JR, Patrick DL, Caldwell ES, Collier AC (2003). Why don't patients and physicians talk about end-of-life care? Barriers to communication for patients with acquired immunodeficiency syndrome and their primary care clinicians. Arch Intern Med 2000; 160:1690-6. chronic illness: qualitative study of patients and parents. BMJ ; 326:305

42. Kassam A, Skiadaresis J, Alexander S, Wolfe J (2014). Parent and Clinician Preferences for Location of End-of-Life Care:Home, Hospital or Freestanding Hospice? Pediatr Blood Cancer; 61:859-864.

43. Johnson LM, Snaman JM, Cupit MC, Baker JN (2014) End-of-Life Care for Hospitalized Children. Pediatr Clin N Am 61. 835-854

44. Cassel CK, Field MJ (1997). Approaching death: Improving care at the end of life. Institute of Medicine. U.S. Committee on Care at the End of Life. Washington, DC: National Academic Press

45. Dussel V, Kreicbergs U, Hilden JM, Watterson J, Moore C, Turner BG, Weeks JC, Wolfe J (2009). Looking beyond where children die: determinants and effects of planning a child's location of death. J Pain Symptom Manage; 37:33-43. 
46. Johnson LM, Snaman JM, Cupit MC, Baker JN (2014). End-ofLife Care for Hospitalized Children. Pediatr Clin N Am 61:835854.

47. Clinical practice guidelines for quality palliative care (2013). 3rd edition. Pittsburgh (PA): National Consensus Project for Quality Palliative Care; 2013. Available at: http://www. nationalconsensusproject.org/NCP_Clinical_Practice_ Guidelines_3rd_Edition.pdf.

48. Hechler T, Blankenburg M, Friedrichsdorf SJ, et al (2008). Parents' perspective on symptoms, quality of life, characteristics of death and end-of-life decisions for children dying from cancer. Klin Padiatr; 220:166e174.

49. Wolfe J, Grier HE, Klar N, et al (2000). Symptoms and suffering at the end of life in children with cancer. N Engl J Med 2000; 342:326e333.

50. Goldman A (2000). Symptoms and suffering at the end of life in children with cancer. [comment]. N Engl J Med; 342:1998. author reply 1998e1999.

51. Theunissen JM, Hoogerbrugge PM, van Achterberg $T$, et al (2007). Symptoms in the palliative phase of children with cancer. Pediatr Blood Cancer; 49:160e165.

52. Schindera C, Tomlinson D, Bartels U, Gillmeister B, Alli A, Sung $L$ (2014). Predictors of Symptoms and Site of Death in Pediatric Palliative Patients With Cancer at End of Life. American Journal of Hospice \& Palliative Medicine; Vol. 31(5) 548-552.

53. Tomlinson D, Hinds PS, Bartels U, Hendershot E, Sung L (2011). Parent reports of quality of life for pediatric patients with cancer with no realistic chance of cure. J Clin Oncol. 29(6):639-645.

54. Wolfe J, Grier HE, Klar N, et al (2000). Symptoms and suffering at the end of life in children with cancer. NEngl JMed. 342(5):326333.

\section{Comment on this article:}

\section{(f) [in is $\mathbf{S}$ ?}

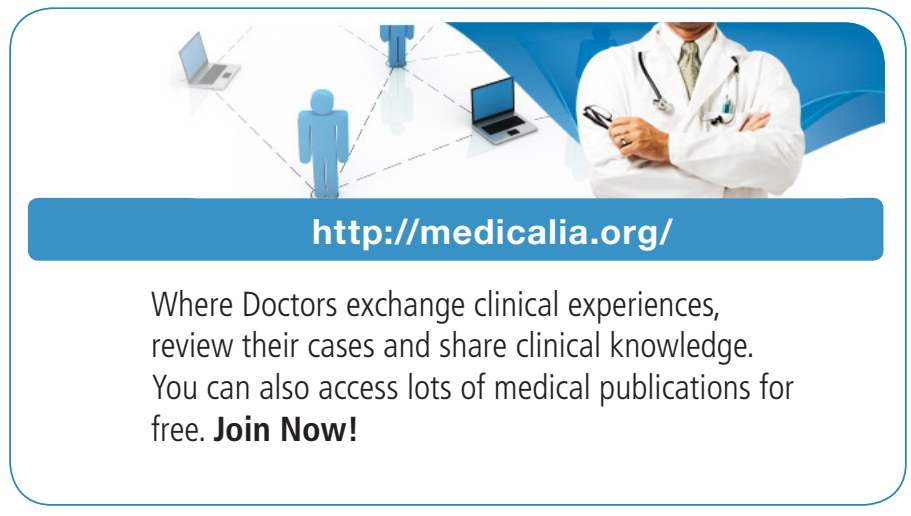

\section{Publish with iMedPub}

http://www.imed.pub

International Archives of Medicine is an open access journal publishing articles encompassing all aspects of medical science and clinical practice. IAM is considered a megajournal with independent sections on all areas of medicine. IAM is a really international journal with authors and board members from all around the world. The journal is widely indexed and classified Q1 in category Medicine. 